\title{
MINERALOGICAL AND GEOCHEMICAL CHARACTERIZATION OF THE OLYMPIAS MINE TAILINGS, NE CHALKIDIKI, GREECE
}

\author{
Zaimis S. ${ }^{1}$, Vavelidis M. ${ }^{1}$, Alifragkis D. ${ }^{2}$, Melfos V. ${ }^{1}$, Kantiranis N. ${ }^{1}$, Daftsis \\ E. $^{3}$ and Gazea E. ${ }^{3}$ \\ ${ }^{1}$ Aristotle University of Thessaloniki, School of Geology, 54124, Thessaloniki, Greece, \\ szaimis@gmail.com \\ ${ }^{2}$ Aristotle University of Thessaloniki, Faculty of Forestry and Natural Environment, 55134, \\ Thessaloniki, Greece \\ ${ }^{3}$ Hellas Gold S.A., Stratoni, 63082, Chalkidiki, Greece
}

\begin{abstract}
The Olympias tailings of NE Chalkidiki, Greece represent the mine wastes produced by the beneficiation of the $\mathrm{Pb}-\mathrm{Zn}$-Au-Ag ore deposit, which is hosted within the carbonate rocks of the Kerdylia Unit. In the present study X-Ray diffraction (XRD), scanning electron microscopy (SEM), optical microscopy, chemical analyses and $p H$ measurements were conducted to determine the tailings mineralogy and chemical composition. The results indicated that they consist of gangue (quartz, rhodochrosite, calcite, dolomite, feldspars, micas, kaolinite and actinolite) and sulfide minerals (pyrite, arsenopyrite, sphalerite, chalcopyrite and galena), reflecting the source ore and its host rock composition, accompanied by traces of Fe-oxides (magnetite, hematite), Fe-oxyhydroxides (goethite) and Mn-oxides, often enriched in $\mathrm{Zn}$ and $\mathrm{Pb}$ and in some cases Fe, Sb and As. Secondary sulfates (gypsum, jarosite) and surface efflorescent salts (ferrohexahydrite, hexahydrite, halotrichite) have also been recognized. The Olympias tailings are generally unoxidized, generating an alkaline environment. However, variations in composition result in the formation of restricted separate phases, such as thin layers and lenses of oxidized material that generates an acidic environment. In terms of precious metals content, the Olympias tailings are enriched in Au (up to $12 \mathrm{~g} / \mathrm{t}$ ) and Ag (up to $20 \mathrm{~g} / \mathrm{t}$ ).
\end{abstract}

Keywords: Mine wastes, secondary minerals, efflorescent salts.

\section{Пєрí $\eta \psi \eta$}

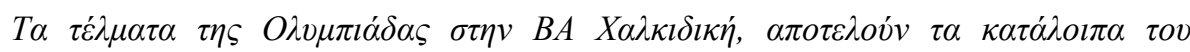

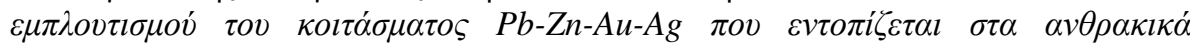

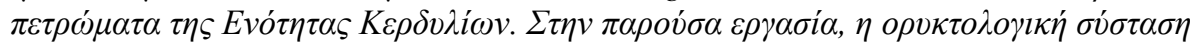

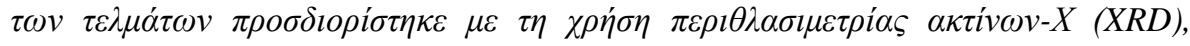

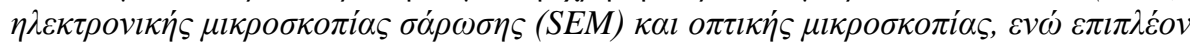

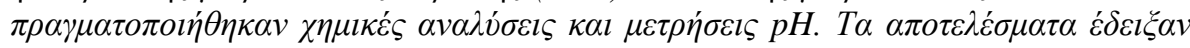

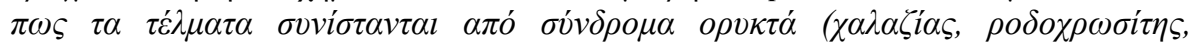

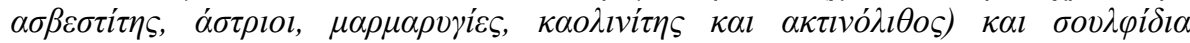

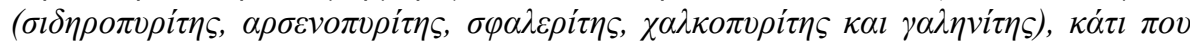

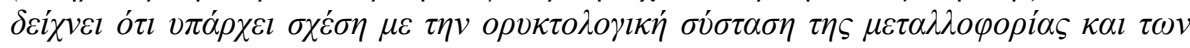




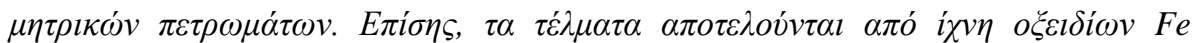

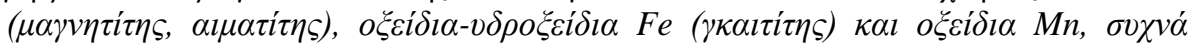

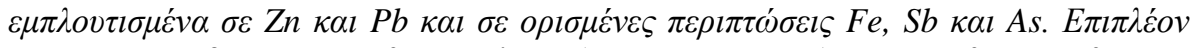

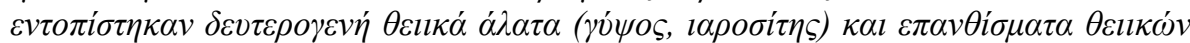

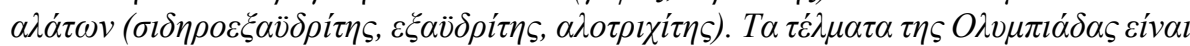

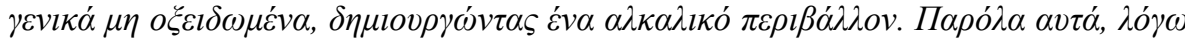

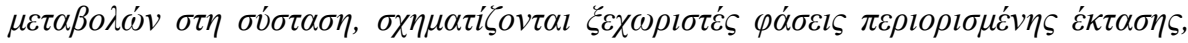

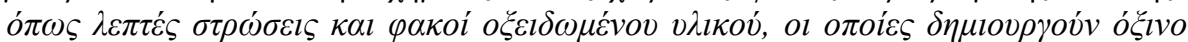

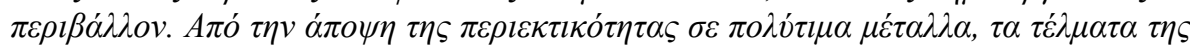

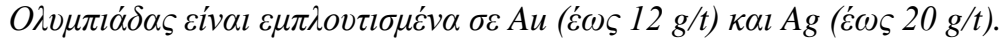

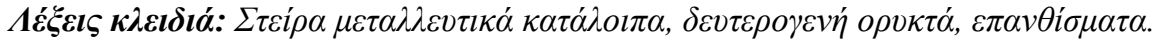

\section{Introduction}

Tailings constitute the residues of ore deposits beneficiation process and are generally located close to mine districts, being the most common mine wastes. They are usually used as backfill underground or stored in open pits, dried and stacked, or pumped into tailings impoundments (Hudson-Edwards et al., 2011). Today, due to the increased demand for precious metals and the availability of improved and more effective beneficiation methods, tailings are often re-assessed and treated as sources of raw materials.

In Olympias, which is part of the "Kassandra mining district" in NE Chalkidiki, Greece, the tailings impoundments are under removal and retreatment (Figure 1a), since 2012, for the production of gold-bearing pyrite-arsenopyrite concentrate by the company Hellas Gold, 95\% owned by Eldorado Gold. After the complete removal, the area, which was used to host the tailing pond and then the tailings impoundments in Olympias, will be returned to its natural greenfield state after replanting (Forward et al., 2011; Alifragkis et al., 2012a, b). The re-process and beneficiation of Olympias tailings in the local concentrator will produce fine tailings, which will be filter-pressed at Olympias and disposed on the existing tailings management facilities in Stratoni, $10 \mathrm{~km}$ southeastern, whereas the coarse residues will initially be sold as aggregates (Forward et al., 2011). The current study is part of a research project for the reclamation of disturbed lands in the wider area of Kassandra mining district, providing an insight in the mineralogical and geochemical composition of the mine tailings. The study was conducted at the Olympias mine tailings, where planting experiments by the Faculty of Forestry and Natural Environment of the Aristotle University of Thessaloniki are in progress, investigating remedial practices on these materials by chemical stabilization using a material rich in Fe-Mn oxides and phytoremediation (Alifragkis et al., 2012a, b) (Figure 1b).

The exposure of mine wastes to the atmosphere and hydrosphere along with the action of microorganisms generates drainage that may be acid and rich in dissolved metals and sulfates (Jamieson, 2011). However, the chemical reactivity and the mobility of heavy metals can be controlled by the mineralogical composition of the tailings. Jamieson (2011) states that in the presence of sufficiently high amounts of carbonate minerals, such as calcite and/or dolomite, the acid drainage may be neutralized. Furthermore, tailings usually contain secondary oxyhydroxides, oxides, sulfates, sulfides, carbonates and silicates (Alpers et al., 1994; Lottermoser, 2010), many of which are fine grained, exhibiting a high capacity for adsorption of potentially toxic metals (Jamieson, 2011). At the surface of the tailings impoundments, secondary minerals are precipitated in the form of soluble sulfate salts after the evaporation of cycling water, caused by the heat produced either by the strongly exothermic reaction of pyrite oxidation or the intense sunlight. 

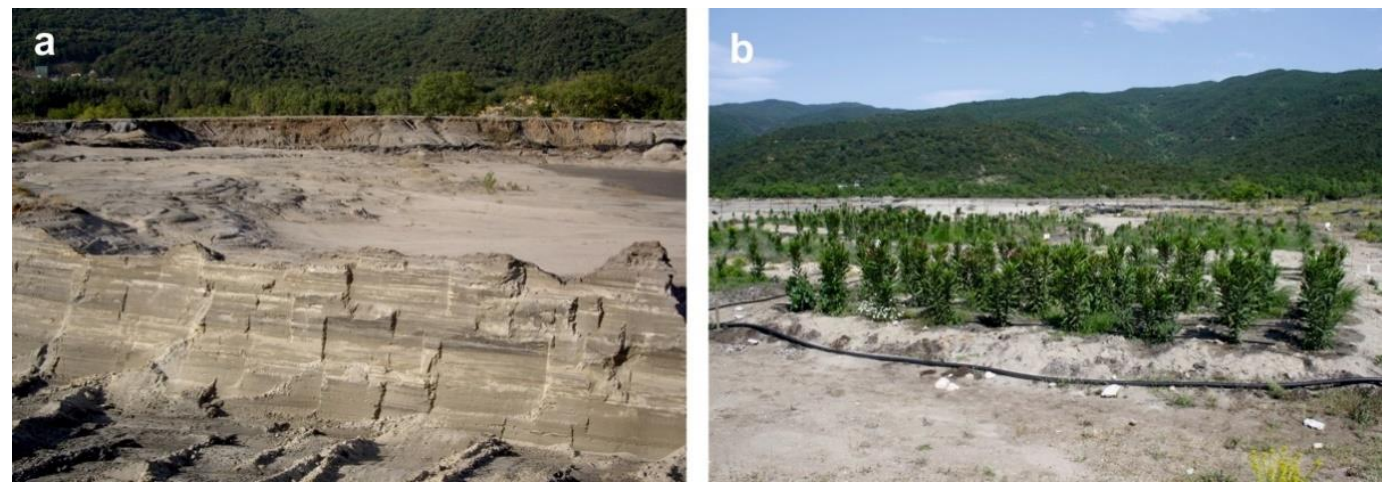

Figure 1 - Olympias mine tailings in NE Chalkidiki. (a) Tailings impoundments in the stage of removal, (b) Planting experiments on the tailings impoundments by the Faculty of Forestry and Natural Environment of the Aristotle University of Thessaloniki.

These minerals are known in the literature as "efflorescent salts" and common examples are melanterite, rozenite, szomolnokite, copiapite, rhomboclase, halotrichite and chalcanthite (Nordstrom, 2011). In this paper we attempt to examine the mineralogy and geochemistry of these materials, for the understanding of tailings mineralogical and chemical composition, theassociation with the primary ore and the host rocks and the nature of secondary mineral phases formed under weathering conditions.

\section{Regional geology and ore deposits in NE Chalkidiki}

The Olympias mining district is part of the broader Kassandra mining district at the NE Chalkidiki Peninsula of northern Greece and geotectonically lies to the Greek part of the Serbo-Macedonian massif (SMM). The SMM is subdivided in two major lithostratigraphic units; the predominant Vertiskos Unit in the northwest and the Kerdylia Unit in the east (Kockel et al., 1977; Burg et al., 1995; Himmerkus et al., 2009). The SMM has been subjected to a metamorphism that reaches upper amphibolite facies (Kilias et al., 1999) and the Kerdylia Unit, where Olympias and the local orebodies are situated, is composed of migmatitic biotite gneisses with intercalations of hornblende gneisses, amphibolite lenses and marbles (upper, intermediate and lower horizon) (Kockel et al., 1977) (Figure 2).

Regarding the igneous activity, the region of NE Chalkidiki is characterized by a post-orogenic acid magmatism with intrusions of porphyry calc-alkaline to shosonitic igneous rocks in SMM during Tertiary (Kockel et al., 1975; Kockel et al., 1977; Fytikas et al., 1984; Tompouloglou et al., 1986; Gilg and Frei, 1994). In the Kassandra mining district, three major Tertiary magmatic rocks have been distinguished by Gilg and Frei (1994); the Stratoni granodiorite (27.9 $\pm 1.2 \mathrm{Ma}, \mathrm{U} / \mathrm{Pb}$ on zircons), the phyllically altered granodioritic to quartz-dioritic porphyry dikes and stocks (minimum age span of $25.4 \pm 0.6$ to $24.4 \pm 0.6 \mathrm{Ma}$, biotite K/Ar) between Fisoka and Aspra Chomata, including Skouries porphyry, and the latest andesite porphyry dikes $(19.1 \pm 0.6, \mathrm{~K} / \mathrm{Ar}$ biotite-whole rock isochrones) at Stratoni region.

The economically most important mineral resources in NE Chalkidiki were/are the $\mathrm{Pb}-\mathrm{Zn}(\mathrm{Au}-\mathrm{Ag})$ carbonate-replacement deposits of Madem Lakkos, Mavres Petres, Olympias and the porphyry $\mathrm{Cu}-$ Au mineralization in Skouries. The Olympias $\mathrm{Pb}-\mathrm{Zn}-\mathrm{Au}-\mathrm{Ag}$ ore deposit, which is intrusion related (e.g. Kalogeropoulos et al., 1989; Gilg and Frei, 1994) and associated to our study, is a stratabound (manto) and locally stratiform or fracture controlled sulfide mineralization, hosted mainly within the lower marble horizon of the Kerdylia Unit and along the contact with the overlying biotite gneiss (Kalogeropoulos et al., 1989). The main host rock of the mineralization is a calcitic and rhodochrosite- and/or Mn calcite-bearing marble. 


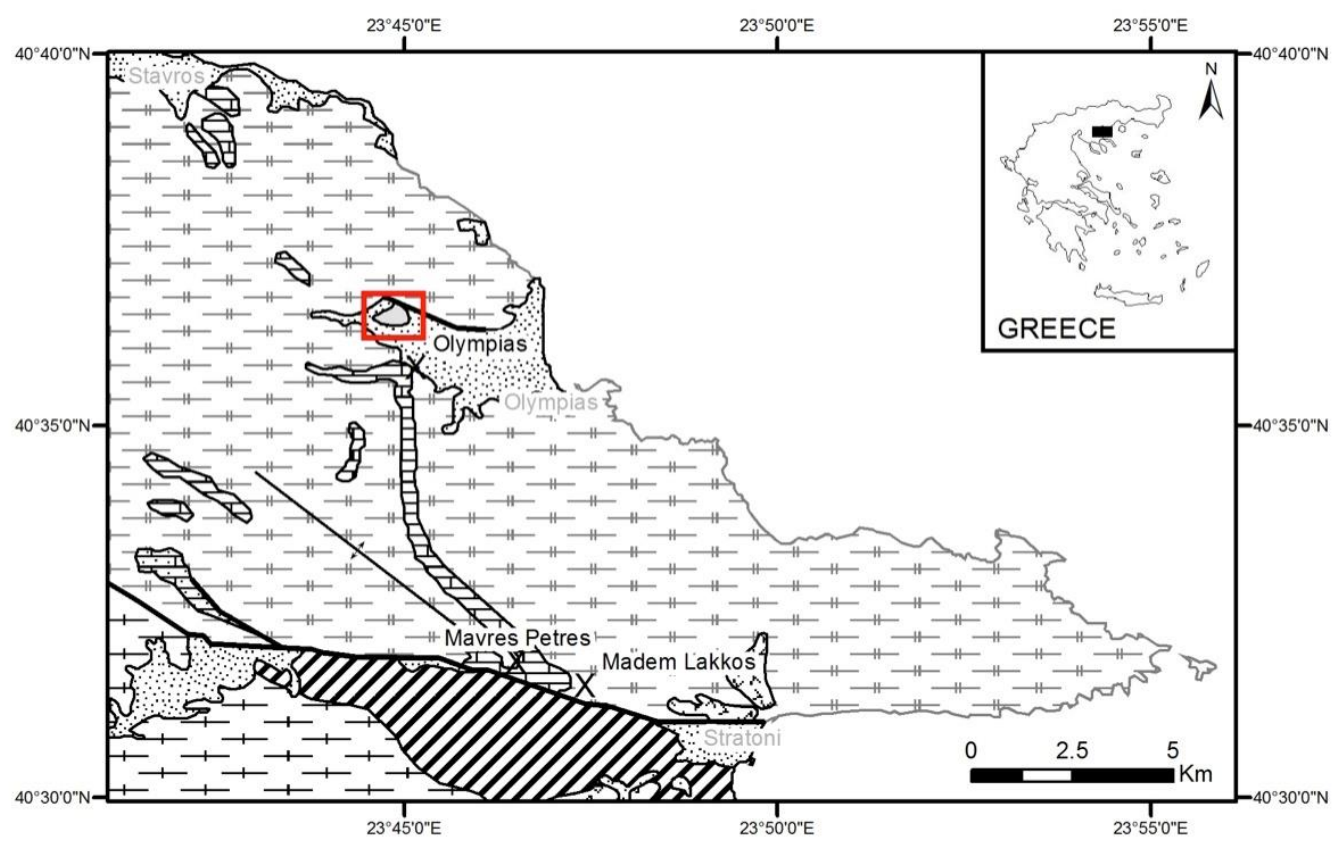

\section{Legend}

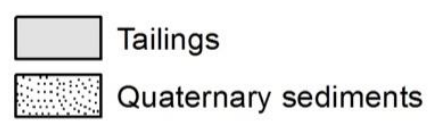

Serbo-Macedonian Massif Vertiskos Unit

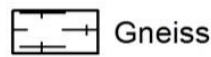

Kerdylia Unit

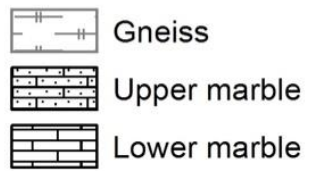

\section{Circum-Rhodope Belt}

212 Amphibolite

\section{Stratoni granodionite \\ Quartz diorite porphyry}

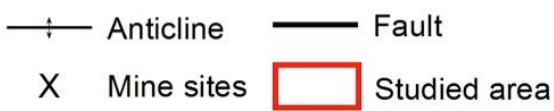

Figure 2 - Simplified geological map of the Kassandra mining district in NE Chalkidiki, Greece (modified after Kockel et al., 1978a, b and Nebel et al., 1991).

Kalogeropoulos et al. (1989), report that the Olympias orebodies consist mainly of pyrite, sphalerite, galena and arsenopyrite, accompanied by sulfides and sulfosalts such as chalcopyrite, tetrahedrite, boulangerite, bournonite, pyrrhotite, marcasite, geocronite and enargite, whereas the gangue minerals consist mainly of quartz, rhodochrosite and calcite. According to Chryssoulis and Cabri (1990), the bulk of the gold in Olympias is "invisible" and is predominantly carried by arsenopyrite and arsenian pyrite.

The broader region of NE Chalkidiki is a historic mining center, as the exploitation of mineral resources for lead and silver started during the archaic period (Vavelidis et al., 1983). Mining, along with gold and silver metallurgy continued during the Byzantine and Ottoman times (Vavelidis and Melfos, 2012). In the modern history, the exploration in the Olympias area commenced in 1954, whereas full production in the Olympias ore deposit started in 1970. It is estimated that $3.64 \mathrm{Mt}$ of mixed sulfide ore were mined between 1976 and 1995, since production stopped, for the production 
of concentrates of galena, sphalerite and pyrite-arsenopyrite, after beneficiation in the local facilities by crushing, milling and differential flotation processes (Papagrigoriou et al., 2010; Forward et al., 2011). Separation of the minerals was achieved in the Olympias concentrator plant through a combination of $\mathrm{pH}$ control and conventional reagents for the depression and activation of the various mineral species (Papagrigoriou et al., 2010; Forward et al., 2011).

The waste residuals, exclusively derived from the Olympias deposit and partially free of the four separated minerals, were discharged in the tailing pond, $500 \mathrm{~m}$ north of the beneficiation facilities in Olympias (Papagrigoriou et al., 2010). Today, the Olympias mine tailings represent the residuals from the former local tailing pond, which cover a geographic area of 26.5 hectares, upon Quaternary sediments (Figure 2).

According to Papagrigoriou et al. (2010) and Forward et al. (2011), apart from the remaining underground resources in Olympias, the operation and development project includes the re-milling and re-processing of the historic tailings in the Olympias concentrator in a rate of 720,000 dry tonnes per annum, for the production of payable gold in concentrate. Forward et al. (2011) report that a drilling campaign of 83 holes indicated a total tonnage of 2,408,403 tonnes, with concentrations of $3.42 \mathrm{~g} / \mathrm{t} \mathrm{Au}$ and $14.25 \mathrm{~g} / \mathrm{t} \mathrm{Ag}$.

\section{Materials and Methods}

The samples used in the current study, are derived from the Olympias tailings disposal area $\left(40^{\circ} 36^{\prime} 28.31^{\prime \prime} \mathrm{N}, 23^{\circ} 44^{\prime} 51.70^{\prime \prime} \mathrm{E}\right)$. The mineralogical composition of tailings was determined by Xray diffraction (XRD) (9 samples), scanning electron microscopy (SEM) and reflected-light optical microscopy (5 samples).

The X-ray diffraction analyses were carried out at the Physics Department and the School of Geology, Department of Mineralogy-Petrology-Economic Geology, Aristotle University of Thessaloniki, using a Rigaku Ultima+ and a Philips PW1710 X-ray diffractometer, respectively, both with CuKa radiation, $1.54056 \AA$ wave length and Ni filter. Scanning electron microscopy (SEM, JEOL JSM-840A) with associated energy dispersive spectroscopy (EDS, Link AN10000) was performed at the Laboratory of Scanning Electron Microscopy of the Aristotle University of Thessaloniki. Optical microscopy was performed at the School of Geology, Department of Mineralogy-Petrology-Economic Geology of Aristotle University of Thessaloniki using a Leitz Laborlux 11 Pol S polarized- and reflected-light microscope.

Sixteen chemical analyses were carried out for the determination of major and trace elements at the Quality Control Laboratory of Hellas Gold S.A. (Stratoni, Chalkidiki) and the ACME Analytical Laboratories Ltd. (Vancouver, Canada). In the first laboratory the analyses of base and trace elements were carried out by inductively coupled plasma atomic emission spectrometry (ICP-AES) and atomic absorption spectroscopy (AAS), Au by fire-assay, Ag by fire-assay/AAS and total S by LECO furnace, whereas in the latter, base and trace elements were also analyzed by inductively coupled plasma atomic emission spectrometry (ICP-AES). The samples were examined for their $\mathrm{pH}$ value at the School of Geology, Department of Mineralogy-Petrology-Economic Geology, Aristotle University of Thessaloniki, using a digital $\mathrm{pH}$ meter (pH301 HANNA Instruments). The $\mathrm{pH}$ was measured by glass-calomel electrode in water: sample pastes (McLean, 1982) of 1:1 ratio (20 g: 20 $\mathrm{ml})$, whereas samples of small quantity measured in 1:5 ratio $(5 \mathrm{~g}: 25 \mathrm{ml})$.

\section{Results and Discussion}

\subsection{Structure and features of the Olympias mine wastes}

The gradual removal of tailings from the depositional site resulted in the exposure of vertical sections (Figure 1a), giving access for sampling from a depth up to $2 \mathrm{~m}$ in average, but also an opportunity for the observation of deeper levels. The Olympias mine tailings consist of parallel 
layers with a thickness of up to $30 \mathrm{~cm}$, often with lenticular intercalations with variant compositions. There are no indications for rhythmical precipitation or graded bedding; in fact it seems that the stratigraphic features were determined by the random disposal of beneficiation residuals from the local concentrator plant. The Olympias tailings are generally unoxidized, exhibiting a light-grey to grey and greyish-yellow to greyish-olive color. However, variations in composition result in the formation of separate oxidized phases, in the form of yellow to brown lenses and thin layers of very limited extend. The texture of the tailings is mainly classified as sandy-silt and silty-sand, while it seems that the coarser components are mainly concentrated at the outer part of the impoundments, close to the termination points of the disposal pipes (Zaimis, 2013). This can be explained by the early precipitation of larger particles and heavier minerals at the margins of the pond, where was the end of the feeding tubes. At the surface of tailings impoundments, secondary minerals are precipitated in the form of white botryoidal aggregates consist of soluble sulfate salts.

\subsection{Mineralogy and mineral chemistry}

The examination of the Olympias tailings indicated that the mineralogical composition in the whole disposal area exhibits a significant resemblance. They mainly consist of gangue minerals (quartz, rhodochrosite, calcite, dolomite, feldspars, micas, actinolite and kaolinite), which are accompanied by sulfides (pyrite, arsenopyrite, chalcopyrite, sphalerite and galena) from the primary ore mineralization, Fe oxides (magnetite, hematite), Fe oxyhydroxides (goethite), Mn oxides, sulfates (gypsum, jarosite) and efflorescent salts (ferrohexahydrite, halotrichite, hexahydrite), formed at the surface of the impoundments. The oxidized tailings are distinguished from the fresh unoxidized, as they represent the materials that contain high amounts of iron sulfates, such as jarosite, formed by the oxidation of the sulfides, providing a characteristic yellow to brown color to the material.

As indicated by the current study, the mineralogy of the Olympias orebody and its host rocks (Kalogeropoulos et al., 1989) is strongly reflected on the Olympias tailings, which contain both primary and secondary minerals. The formation of secondary minerals in Olympias tailings is predominantly associated with the weathering of the included sulfides and the dissolution of primary carbonates. However, the use of $\mathrm{CaO}$ and /or $\mathrm{Ca}(\mathrm{OH})_{2}$ during the ore beneficiation process may have had an important contribution in the formation of certain secondary phases, such as gypsum.

The Olympias tailings are dominated by quartz (17 to $44 \mathrm{wt} . \%$ ) and carbonate minerals, which consist of rhodochrosite (up to $25 \mathrm{wt} . \%$ ), calcite (up to $23 \mathrm{wt} . \%$ ) and dolomite (up to $17 \mathrm{wt} . \%$ ). Feldspars, mainly albite (up to $11 \mathrm{wt} . \%$ ) and microcline (up to $10 \mathrm{wt} . \%$ ) have also been observed. Mica flakes consist mainly of muscovite (up to $10 \mathrm{wt} . \%$ ) and biotite (up to $10 \mathrm{wt} . \%$ ). Minor amounts of kaolinite have only been determined by XRD (up to $5 \mathrm{wt} . \%$ ), whereas from the amphibole group, $\mathrm{Ca}-\mathrm{Mg}$-amphibole has been identified by XRD in traces, only in one sample.

Pyrite is the dominant sulfide mineral in the tailings (up to $9 \mathrm{wt} . \%$ ), containing 46.71 to $46.92 \mathrm{wt} . \%$ Fe. Pyrite occurs either in the form of separate grains or incorporated with carbonates or silicates and/or other sulfides, such as sphalerite and galena. In the oxidized tailings, the alteration of pyrite is more extensive than in the unoxidized, replaced by Fe oxyhydroxides, mainly goethite. Arsenopyrite is the second most common sulfide (up to $4 \mathrm{wt} . \%$ ). It is often found as separate grains, usually fractured, or intergrown with gangue minerals.

Sphalerite occurs in traces (up to $2 \mathrm{wt} . \%$ ), as separate grains or intergrown with quartz and sulfides such as pyrite and galena. Chalcopyrite blebs have also been observed in sphalerite, which is a typical texture for the sphalerite from Olympias, according to Kalogeropoulos and Economou (1987). Regarding the chemical composition, sphalerite contains 54.86 to 60.99 wt. $\% \mathrm{Zn}, 5.04$ to $10.96 \mathrm{wt} . \%$ $\mathrm{Fe}$ and traces of Mn (up to $0.66 \mathrm{wt} . \%$ ). Galena is found rarely as separate grains. It is mostly intergrown with other sulfides such as sphalerite and pyrite, but also with gangue minerals mainly quartz and calcite. Chalcopyrite, besides forming blebs in sphalerite, occurs in traces containing 33.65 to 35.49 wt. $\% \mathrm{Cu}$ and 29.50 to $30.50 \mathrm{wt}$ \% $\mathrm{Fe}$. 
Goethite occurs mainly in the form of replacement rims around pyrite or in co-existence with jarosite. As indicated by SEM-EDS microanalyses, it contains FeO (62.25 to 94.93 wt.\%) with ZnO (up to 10.37 wt.\%), $\mathrm{PbO}$ (up to 8.77 wt.\%), $\mathrm{As}_{2} \mathrm{O}_{3}$ (up to 10.34 wt.\%) and $\mathrm{MnO}$ (up to 3.27 wt.\%).

Manganese oxides have been observed in traces, in the form of sub-rounded to rounded grains of up to $2.5 \mathrm{~mm}$ in length. They are often enriched in $\mathrm{Zn}$ and $\mathrm{Pb}$ and in some cases $\mathrm{Fe}, \mathrm{Sb}$ and $\mathrm{As}$, as well as $\mathrm{K}$ and $\mathrm{Ca}$. Due to their extensive elemental variation, the Mn oxides exhibit various mineral phases, which were difficult to identify. The majority of the Mn oxides grains consist of $\mathrm{MnO}(70.51$ to 100.00 wt.\%), being rich in $\mathrm{ZnO}$ (up to $19.81 \mathrm{wt} \%$ ), $\mathrm{PbO}$ (up to $7.82 \mathrm{wt} . \%$ ), $\mathrm{K}_{2} \mathrm{O}$ (up to 4.7 wt.\%) and $\mathrm{CaO}$ (up to 3.74 wt.\%), whereas Fe-Mn oxides phases (FeO 10.05 - 62.18 wt.\%, MnO 12.45 71.85 wt.\%) occur as intergrowths. Occasionally, coatings of highly enriched phases in $\mathrm{Zn}, \mathrm{Pb}, \mathrm{Fe}$, $\mathrm{Sb}$ and $\mathrm{As}$, were observed under the SEM, around the Mn oxide grains. These rims contain various concentrations of $\mathrm{MnO}$ (48.33 to $89.76 \mathrm{wt} . \%$ ), $\mathrm{ZnO}$ (2.25 to 38.49 wt.\%) and $\mathrm{PbO}$ (up to 22.35wt.\%), along with $\mathrm{FeO}$ (up to 7,88 wt.\%), $\mathrm{Sb}_{2} \mathrm{O}_{3}$ (up to 7.60 wt.\%) and $\mathrm{As}_{2} \mathrm{O}_{3}$ (up to 5.28 wt.\%). The most sufficient assumptions for the formation of the Mn oxides are to be secondary phases, controlled by adsorption/co-precipitation mechanisms.

Leckie et al. (1980) report that co-precipitation and adsorption reactions with $\mathrm{Fe}(\mathrm{OH})_{3}$ can be effective in the removal of metals such as $\mathrm{Cd}, \mathrm{Cu}, \mathrm{Zn}$, As and Se from waste-water streams. Likewise in Olympias, the presence of $\mathrm{Zn}, \mathrm{Pb}, \mathrm{Sb}$ and $\mathrm{As}$ in $\mathrm{Fe}$ and $\mathrm{Mn}$ oxides enhances the role of these materials as trace elements retentive agents.

Jarosite is found only in the oxidized tailings, where is the predominant constituent (up to 18 wt.\%), coexisting sometimes with goethite, exhibiting replacement textures on grains of obscure origin. The SEM-EDS microanalyses indicated that jarosite contains $\mathrm{K}_{2} \mathrm{O}$ (9.77 to 10.50 wt.\%), $\mathrm{FeO}$ (50.95 to 51.48 wt.\%) and $\mathrm{SO}_{3}$ (38.02 to $\left.39.28 \mathrm{wt} . \%\right)$. Another common sulfate mineral in tailings is gypsum (up to $18 \mathrm{wt} . \%$ ), which often forms euhedral crystals of up to $2 \mathrm{~mm}$ in length, indicating a secondary formation.

Blowes and Jambor (1990), suggest that minor amounts of ferrous sulfates $\left(\mathrm{FeSO}_{4} \cdot \mathrm{nH}_{2} \mathrm{O}\right)$ in dried tailings, may form as ephemeral precipitates on the sun-baked surface crust, a phenomenon that has also been observed in Olympias tailings. White botryoidal aggregates of up to $1 \mathrm{~mm}$ in diameter have been observed at the surface of the Olympias tailings impoundments as efflorescent salts. On the basis of qualitative and semi-quantitative identification, the white aggregates, collected from an exposure in the surface of tailings piles, consist mainly of ferrohexahydrite (67 wt.\%) and gypsum (4 wt.\%), whereas quartz (15 wt.\%) and calcite (13 wt.\%) probably represent impurities, as observed in the SEM. Additionally, Mg- and Fe-Al-sulfates have been observed under the SEM, identified, based on their chemistry, as hexahydrite and halotrichite, respectively.

\subsection{Geochemistry}

The results from bulk chemical analyses indicate that there is a strong relation between the geochemistry and the mineralogy. Within tailings, high Fe concentrations $(1.19-7.43$ wt.\%) are associated with the presence of iron sulfides, their alteration products and the contained ferromagnesian silicates. Total $\mathrm{S}$ is also elevated $(0.80-5.28 \mathrm{wt} . \%)$, reflecting the contribution of sulfides and sulfate salts. Arsenic occurs in elevated amounts (up to $>1 \mathrm{wt} . \%$ ) and is associated with the Fe-sulfides, mainly arsenopyrite, on the basis of mineralogical results. Manganese (up to $>1$ wt.\%) is mainly associated with rhodochrosite, while $\mathrm{Mg}(0.14$ to $1.67 \mathrm{wt} . \%)$ mainly reflects the presence of dolomite. Calcium (1.87 - 11.97 wt.\%) is associated with Ca-carbonates and sulfates.

In the Olympias tailings several metals are associated with the contained sulfides and are of particular economic importance such as $\mathrm{Au}$ and $\mathrm{Ag}$. Gold reaches $12 \mathrm{~g} / \mathrm{t}$ and silver varies from 4 to $20 \mathrm{~g} / \mathrm{t}$, being strongly associated with galena, as indicated by the chemical analyses. The most abundant trace metals, considering only the absolute values (excluding the above upper detection limits values) were As (2684 - $26960 \mathrm{~g} / \mathrm{t}), \mathrm{Pb}(1318$ - $8802 \mathrm{~g} / \mathrm{t}), \mathrm{Zn}$ (709 - $7733 \mathrm{~g} / \mathrm{t}), \mathrm{Sb}$ (147 - 672 $\mathrm{g} / \mathrm{t})$ and $\mathrm{Cu}(62-665 \mathrm{~g} / \mathrm{t})$. 
The mineralogical composition affects the grade of acidity, which is measured in $\mathrm{pH}$. The Olympias mine tailings, which are predominantly unoxidized, do not indicate significant $\mathrm{pH}$ deviation, ranging from 7.5 to 8.1. The increased amount of carbonates, that prevails in the majority of samples of the unoxidized tailings and the relatively low concentration of sulfides and sulfates are factors that determine their alkaline nature. However, the oxidized type of tailings, which exhibit lower content in carbonate minerals, has significantly lower $\mathrm{pH}$, equal to 3.0, suggesting an acidic environment.

\section{Conclusions}

The mine wastes deposited in Olympias, NE Chalkidiki, were derived from the beneficiation of the Olympias $\mathrm{Pb}-\mathrm{Zn}-\mathrm{Au}-\mathrm{Ag}$ carbonate-replacement ore and their mineralogical composition shows a significant resemblance with the source ore and host rocks. The results indicate that they predominantly consist of gangue minerals such as quartz, rhodochrosite, calcite and dolomite and minor sulfides, such as pyrite, arsenopyrite, sphalerite, chalcopyrite and galena. Due to the increased amount of contained carbonate minerals the tailings generate an alkaline environment with $\mathrm{pH}$ values between 7.5 and 8.1. However, variations in composition result in the formation of separate phases, such as thin layers and lenses of oxidized material that generates an acidic environment. This oxidized material is characterized by its yellow colour, the high content in jarosite and the low content in carbonates. The tailings also contain minor quantities of iron and manganese oxides, often enriched in $\mathrm{Zn}$ and $\mathrm{Pb}$ and in some cases Fe, Sb and As, most probably after adsorption/coprecipitation mechanisms. Sulfates, such as gypsum and jarosite and surface efflorescent salts, identified as ferrohexahydrite, hexahydrite and halotrichite constitute the main secondary phases. Arsenic, $\mathrm{Pb}, \mathrm{Zn}, \mathrm{Sb}$ and $\mathrm{Cu}$ have been detected in high concentrations, whereas in terms of precious metals content, the Olympias tailings are enriched in $\mathrm{Au}$ (up to $12 \mathrm{~g} / \mathrm{t}$ ) and $\mathrm{Ag}$ (up to $20 \mathrm{~g} / \mathrm{t}$ ).

\section{Acknowledgements}

We would like to thank Professor Dr. G. Voutsas from the Physics Department, Aristotle University of Thessaloniki for providing XRD analyses. For the XRD analyses, provided by the School of Geology, Department of Mineralogy-Petrology-Economic Geology, Aristotle University of Thessaloniki, we would like to thank Prof. Dr. A. Filippidis. Assistant Professor Dr. L. Papadopoulou, School of Geology, Aristotle University of Thessaloniki, is especially thanked for her valuable assistance with the SEM. We would also like to express our gratitude to Hellas Gold S.A. for providing part of the chemical analyses and the permission for obtaining the samples. Finally, special thanks are due to Dr. I. Georgiadis for his useful comments on the entire study.

\section{References}

Alifragkis, D., Voulgaridou, H., Orfanoudakis, M., Daftsis, E., Characlias, J., Papaioannou, A., Vavelidis, M., Alifragkis, E., Voulgaropoulou, M. and Galatsianou, A., 2012a. Reclamation of mining waste (cake) of Kassandra Chalkidikis mines after stabilization with rich in Fe and Mn oxides materials, $14^{\text {th }}$ Congress of the Hellenic Soil Science Society (HSSS), Thessaloniki, Proceedings of the Hellenic Soil Science Society (HSSS), (in Greek with English abstract) (in press).

Alifragkis, D., Voulgaridou, H., Orfanoudakis, M., Daftsis, E., Papaioannou, A., Vavelidis, M., Characlias, J., Alifragkis, E., Voulgaropoulou, M. and Galatsianou, A., 2012b. Reclamation of old tailing disposal area of Olympias Halkidiki mine after stabilization with rich in Fe and Mn oxides materials, $14^{\text {th }}$ Congress of the Hellenic Soil Science Society (HSSS), Thessaloniki, Proceedings of the Hellenic Soil Science Society (HSSS), (in Greek with English abstract) (in press).

Alpers, C.N., Blowes, D.W., Nordstrom, D.K. and Jambor, J.L., 1994. Secondary minerals and acid mine-water chemistry. In: Jambor, J.L. and Blowes, D.W., eds., Environmental Geochemistry of Mine Wastes, Mineralogical Association of Canada Short Course, 247-270. 
Blowes, D.W. and Jambor, J.L., 1990. The pore-water geochemistry and the mineralogy of the vadose zone of sulfide tailings, Waite Amulet, Quebec, Canada, Applied Geochemistry, 5(3), 327-346.

Burg, J.P., Godfriaux, I. and Ricou, L.E., 1995. Extension of the Mesozoic Rhodope thrust units in the Vertiskos-Kerdillion Massifs (Northern Greece), C. R. Acad. Sci., Paris. 320(9), 889-896.

Chryssoulis, S.L. and Cabri, L.J., 1990. Significance of gold mineralogical balances in mineral processing, Trans. Inst. Min. Metall., 99, C1-C10.

Forward, P., Francis, A. and Liddell, N., 2011. Technical Report on the Olympias Project, Au Pb Zn Ag Deposit, Northern Greece, European Goldfields Ltd., Whitehorse, Yukon, 213 pp.

Fytikas, M., Innocenti, F., Manetti, P., Peccerillo, A., Mazzuoli, R. and Villari, L., 1984. Tertiary to Quaternary evolution of volcanism in the Aegean region, Geological Society, London, Special Publications, 17(1), 687-699.

Gilg, H.A. and Frei, R., 1994. Chronology of magmatism and mineralization in the Kassandra mining area, Greece: The potentials and limitations of dating hydrothermal illites, Geochimica et cosmochimica acta, 58(9), 2107-2122.

Himmerkus, F., Reischmann, T. and Kostopoulos, D., 2009. Serbo-Macedonian revisited: a Silurian basement terrane from northern Gondwana in the Internal Hellenides, Greece, Tectonophysics, 473(1), 20-35.

Hudson-Edwards, K.A., Jamieson, H.E. and Lottermoser, B.G., 2011. Mine wastes: Past, present, future, Elements, 7(6), 375-380.

Jamieson, H.E., 2011. Geochemistry and mineralogy of solid mine waste: essential knowledge for predicting environmental impact, Elements, 7(6), 381-386.

Kalogeropoulos, S.I. and Economou, G.S., 1987. A study of sphalerite from the carbonate-hosted $\mathrm{Pb}-\mathrm{Zn}$ sulfide deposits of the Eastern Chalkidiki Peninsula, Northern Greece, Canadian Mineralogist, 25, 639-646.

Kalogeropoulos, S.I., Kilias, S.P., Bitzios, D.C., Nicolaou, M. and Both, R.A., 1989. Genesis of the Olympias carbonate-hosted $\mathrm{Pb}-\mathrm{Zn}(\mathrm{Au}, \mathrm{Ag})$ sulfide ore deposit, eastern Chalkidiki Peninsula, northern Greece, Economic Geology, 84(5), 1210-1234.

Kilias, A., Falalakis, G. and Mountrakis, D., 1999. Cretaceous-Tertiary structures and kinematics of the Serbomacedonian metamorphic rocks and their relation to the exhumation of the Hellenic hinterland (Macedonia, Greece), International Journal of Earth Sciences, 88(3), 513-531.

Kockel, F., Mollat, H. and Walther, H.W., 1977. Erläuterungen zur Geologischen Karte der Chalkidhiki und angrenzender Gebiete 1:100.000 (Nord-Griechenland), Bundesanstalt für Geowissenschaften und Rohstoffe, Hannover.

Kockel, F., Mollat, H. and Gundlach, H., 1975. Hydrothermally altered and (copper) mineralized porphyritic intrusions in the Serbo-Macedonian Massif (Greece), Mineralium deposita, 10(3), 195-204.

Kockel, F., Mollat, H., Walther, H.W., Antoniades, P. and loannides, K., 1978a. Stavros sheet (1:50,000), geological map of Greece, Athens, Greece, Inst. Geol. Mining Research.

Kockel, F., Mollat, H., Walther, H.W., Antoniades, P. and loannides, K., 1978b. Stratoniki sheet (1:50,000), geological map of Greece, Athens, Greece, Inst. Geol. Mining Research.

Leckie, J.O., Benjamin, M.M., Hayes, K., Kaufman, G. and Altmann, S., 1980. Adsorption/coprecipitation of trace elements from water with iron oxyhydroxide, Rep. prepared for the Electric Power Research Institute, EPRI-RP-910.

Lottermoser, B., 2010. Mine wastes: Characterization, Treatment and Environmental Impacts, Springer-Verlag Berlin Heidelberg, 400 pp.

McLean, E.O., 1982. Soil pH and lime requirement. Methods of soil analysis. Part 2, Chemical and microbiological properties, 199-224.

Nebel, M.L., Hutchinson, R.W. and Zartman, R.E., 1991. Metamorphism and polygenesis of the Madem Lakkos polymetallic sulfide deposit, Chalkidiki, Greece, Economic Geology, 86(1), 81-105.

Nordstrom, D.K., 2011. Mine Waters: Acidic to Circmneutral, Elements, 7(6), 393-398. 
Papagrigoriou, S., Papadaki, A., Katselis, I., Kotzageorgis, G., Mpekiaris, I., Tentes, G., Manitara, K., Meletiou, A., Mprousti, P., Mpakouras, X., Kavvadia, A., Sfikas, G., Adamopoulos, T., Apostolidis, I., Hallmann, B., Ivovic, M., Vogiatzis, K., Kassomenos P., Charalampopoulou, M. and Toris, N., 2010. Environmental impact assessment of the mining and metallurgical plants of Hellas Gold S.A. in Chalkidiki, ENVECO S.A., Athens, (in Greek), 1074 pp.

Tompouloglou, C., Campiglio, C. and Bellon, H., 1986. Les manifestations magmatiques dans le Massif Serbo-Macédonien (Grèce) à l'Oligo-Miocène. Précisions apportées par l'analyse radiométrique 40K-40Ar. Comptes rendus de l'Académie des sciences. Série 2, Mécanique, Physique, Chimie, Sciences de l'univers, Sciences de la Terre, 302(7), 431-436.

Vavelidis, M. and Melfos, V., 2012. Study of the ancient metallurgical works in Kipouristra, Olympiada (Ancient Stageira), NE Chalkidiki, Scientific Annals of the Faculty of Geology, School of Science, Aristotle University of Thessaloniki, Special Volume 101, 9-16 (in Greek).

Vavelidis, M., Pernicka, E. and Wagner, G.A., 1983. Untersuchungen in den $\mathrm{Pb}-\mathrm{Ag}$ und $\mathrm{Au}-$ Vorkommen von NE-Chalkidiki (Nordgriechenland), Beihefte zum Eurp. J. Miner., 212-213.

Zaimis, S., 2013. Mineralogical and geochemical investigation at reclamation sites of old tailings disposal area at Olympias mining district, NE Chalkidiki. Master thesis, Faculty of Geology, Aristotle University of Thessaloniki, Greece (in Greek with English abstract). 